\title{
Saffron in Jammu \& Kashmir
}

\author{
Daawar Bashir Ganaie ${ }^{1 *}$, Yadvinder Singh ${ }^{2}$ \\ ${ }^{l}$ post Graduate Student of Geography, Punjabi University Patiala India \\ ${ }^{2}$ professor of Geography, Punjabi University patiala India
}

"Corresponding Author: Daawar Bashir Ganaie, post Graduate Student of Geography, Punjabi University Patiala India

\begin{abstract}
This study aims at studying the cultivating practices, different factors which are responsible for declining the production of saffron (Crocus sativus) in Jammu \& Kashmir. Kashmir is famous for the cultivation of quality saffron from about 750 A.D and is one of the major saffron producing areas of the world. Unfortunately, from last couple of decades the production of Saffron in Kashmir has been severely affected and has shown a declining trend. Here, the study is about discussing the problems like nonavailability of quality planting material, absence of irrigation facilities, lack of disease control pests, nonavailability of suitable markets and reasonable profits to cultivators. Here, it is also been discussed that precipitation in valley has an impact on the productivity and yield of saffron production. Furthermore, it also discusses about the steps taken by Government in the form of Saffron Mission 2010, and its role on this Golden Crop.
\end{abstract}

\section{INTRODUCTION}

Saffron (Crocus sativus), originated from the Arabic word 'Zafaran' which comes from the Persian word 'Zarparan' meaning "flowers of golden petals". Its secrets stem from the dried red stigmas which accumulate large amounts of three glycosylated apocarotenoids, namely crocin, picro crocin and safranal, which, among the more than 150 volatile and aroma yielding compounds, contribute to the colour, bitter flavour and aroma so typical of saffron (https://en.m.wikipedia.org/wiki/ Saffron). The spice is used as flavouring and colouring agent in food and is a vital part of the dye, perfumery and flavouring industries. Saffron also has countless biological properties like anticancer, antimutagenic and antioxidant. As a result, saffron fetches the highest price as a spice in the world, depending upon the country of its production. Its production is typically favoured in countries where labour is cheap, such as Iran and Azerbaijan, but is also produced in countries like Greece, Switzerland, Spain, Argentina or the USA and newer areas being brought under its cultivation, viz. China and Japan (Husaini et, al. 2013). Kashmir is one of the major saffron producing regions of the world.

Crown in the Karewas of Kashmir and Bhaderwah of Jammu Division, it is an important cash crop providing employment to about 5 per cent of the total rural workforce in Valley of Kashmir (Husain. M.). This valuable "golden" spice is known as 'Kum Kum' and 'Kesar' in Sanskrit, and 'Koung' in Kashmiri language. It is being said that Saffron in Valley originated from the Takshak spring located in Zewan village, almost $11 \mathrm{~km}$. away from Srinagar and then from there it had spread to its adjoining areas. Kashmir is the second largest contributor of saffron to the global market (Farooq et, al. 2016). Saffron is being grown in the Pampore Karewa of Kashmir from very ancient times. Perfectly, it cannot be mentioned here that when the cultivation of saffron was started in Kashmir, but Saffron is being reported to have been an important ingredient of the prescriptions of Veghbhatta and Sustratta who practiced medicine about 500 B.C. Its cultivation was in vogue Pampore (Padam-pure) even when Kalidas wrote his literary masterpiece Shakuntala and Meghdoot. Kalhan, the well-known historian of Kashmir started in Rajterangani that saffron was under cultivation in Kashmir even before the regime of Lalitadatiya during 725 A.D. Abul Fazal in his Ain-i-Akbari says that the saffron fields in blossom afford a prospect that would enchant those who were most difficult to please. Despite all these stories and beliefs, it is not clear when the saffron cultivation was started in the Valley of Kashmir (Husain. M.). Kashmir's Tehsil of Pampore is the center of saffron cultivation in the Valley 
and is located at $34^{\circ} 1^{\prime} \mathrm{N}, 74^{\circ} 56^{\prime} \mathrm{E}$, with an average elevation of 1574 metres (AMSL). Khunmoh, Zewan, Balhama, Sampora, Ladhoo, Chandhara, Woyan, Khrew, Shar Konibal, Dussu, Namblabal, Kadlabal, Hatiwara, Samboora and Lethpora are prominent saffron villages of Tehsil Pampore where this cultivation is being practiced. The cultivation of saffron firstly started in this area and with the passage of time people in the adjoining districts started cultivation of this crop. At present, the crop is being cultivated in some areas of adjoining districts like Srinagar, Ganderbal, Budgam, Shopian, Anantnag, Bhaderwah and Kulgam. But, still the main hub of Saffron cultivation is considered as Pampore area of district Pulwama.

\section{Botanical Classification}

Saffron is classified into Domain Eukarya, Kingdom Plantae, Phylum Magnoliophyta (Angiosperm), Class Liliopsida (Monocot), Order Asparagales, Family Iridaceae, Genus Crocus and Species C. sativus.

\begin{tabular}{|l|l|}
\hline DOMAIN & Eukarya \\
\hline KINGDOM & Plantae \\
\hline PHYLUM & Magnoliophyta (Angiosperm) \\
\hline CLASS & Liliopsida (Monocot) \\
\hline ORDER & Asparagales \\
\hline FAMILY & Iridaceae \\
\hline GENUS & Crocus \\
\hline SPECIES & Sativus \\
\hline
\end{tabular}

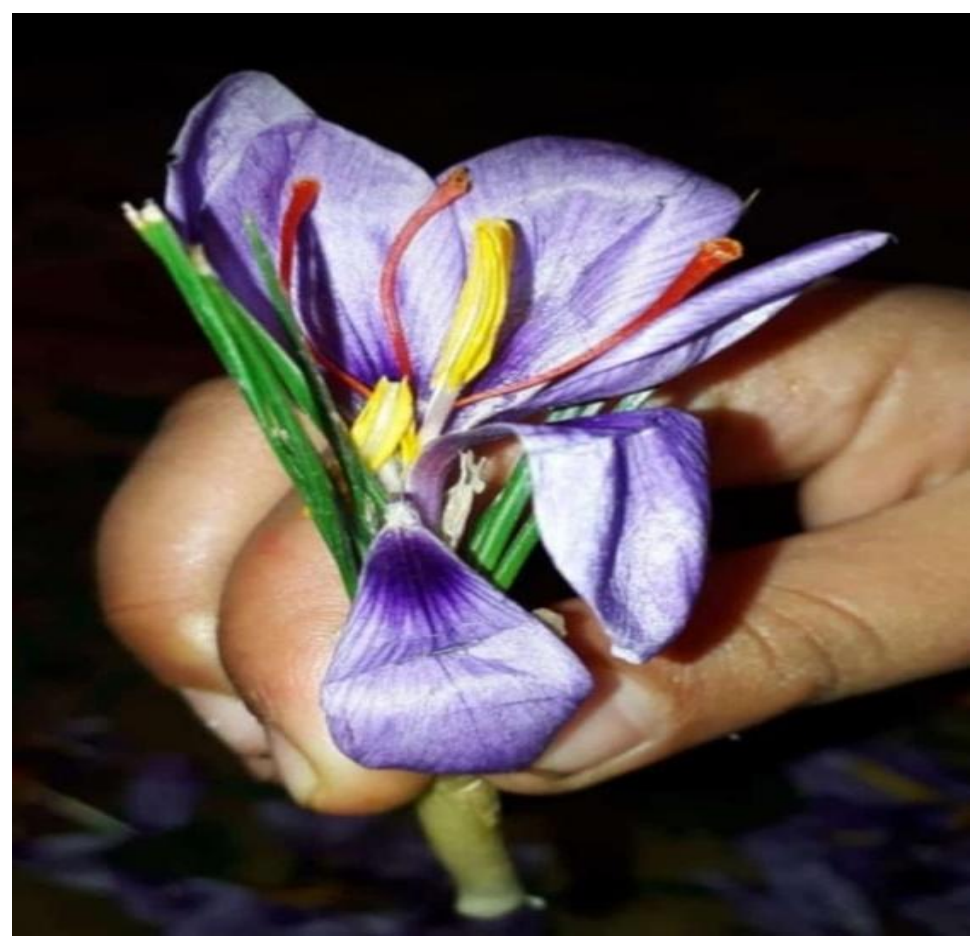

Figure1. Saffron Flower

\section{OBJECTIVES UNDER THIS STUdY}

The Study has following main objectives:

- To show the cultivation practices opted by farmers/cultivators from the ancient times and changes came in those practices at present.

- To show the distribution the development of crop and when this crop has been started cultivating in the State.

- To analyze the production and productivity rate of the crop from past two to three decades and the causes of for the declining productivity of crop and decline of area under this crop.

- To analyze the steps taken by governments of state and centre in saving this Golden Crop from threat of extinction. 


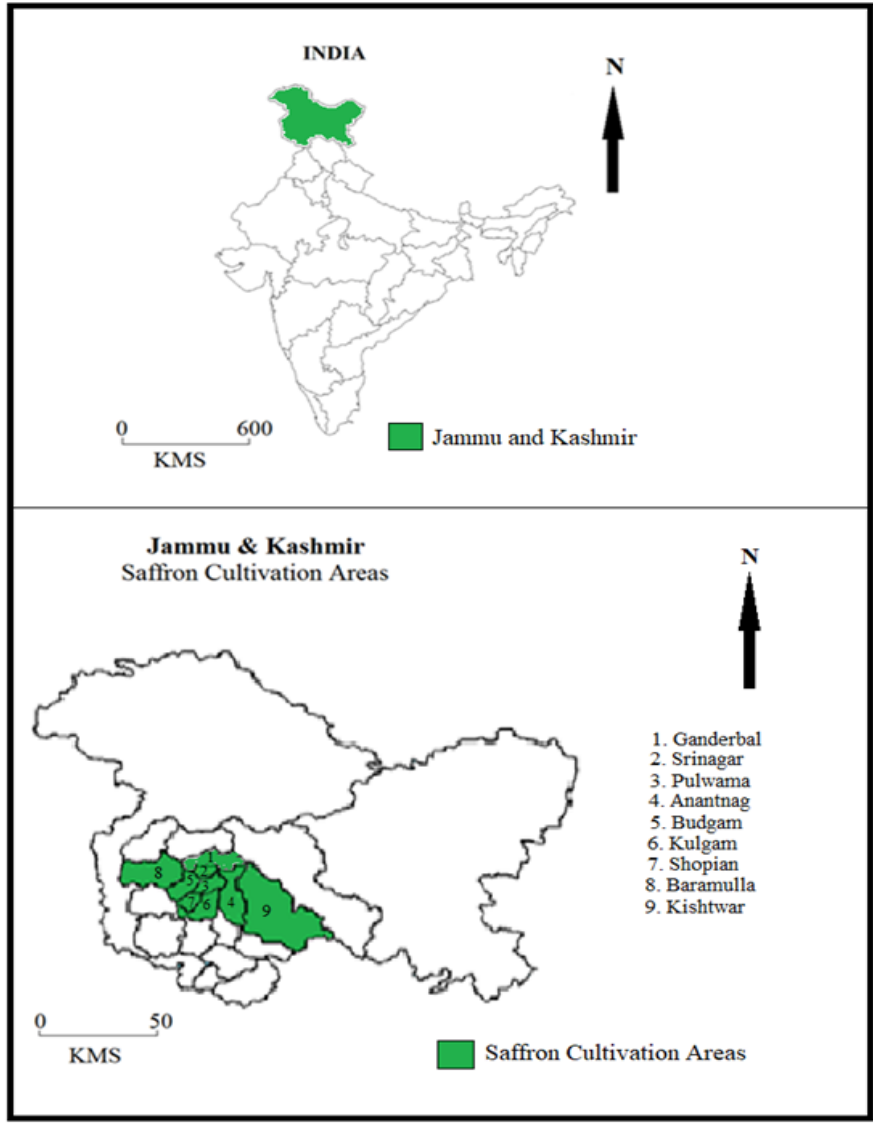

Source: www.mapsofindia.com

MapNo.1. Location of the Study Area

\section{Cultivation Practices of SAfFron In Jammu ANd KaShmir}

Saffron in the Valley is being cultivated in the Karewas of Pampore in Pulwama and Bhaderwah districts of Jammu and Kashmir, and the places where we can find the loamy soils which suits the growth of saffron. Saffron is a perennial crop, lasting for about 10-15 years after sowing (Husain. M.). A new cultivator who has a plan to go for saffron cultivation starts preparing the land one year before the sowing of corms (seeds of saffron). This process needs a lot of labour force and financial support, as the farmer has to prepare his land for good growth of saffron. Farmers optioned that, before going for Saffron cultivation, the land should be cultivated by oilseeds, in a year before sowing saffron corms, as it is good for growth of saffron corms in the succeeding year.

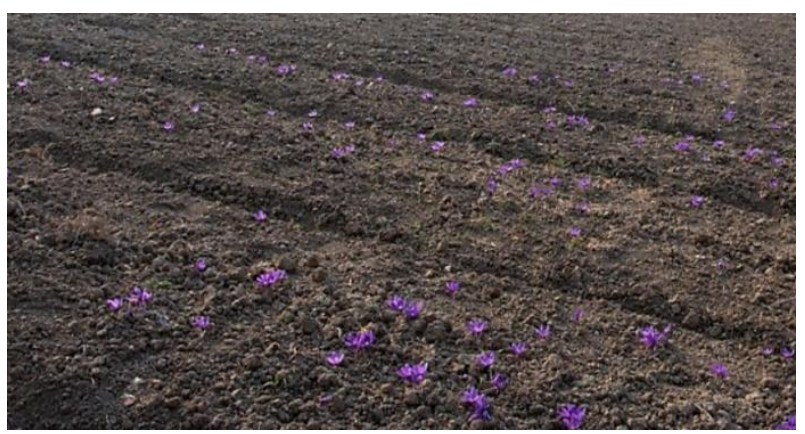

Figure2. Saffron flowering in Fields of Pampore, Pulwama

When the spring season (Sonth) in the Valley starts, the concrete preparations for the Saffron cultivation also gets started, by ploughing the land in the starting month of spring season (March or April). Moreover, it also depends upon the weather conditions, if rains or more then the ploughing process is delayed for some time as more moisture soils are not good for corms as it can affect the health of corms and the land will not be ploughed efficiently as needed for good cultivation. After ploughing, a good quantity of green manure (farmyard manure) is applied ( $30-40$ tonnes per hectare). If the weather conditions are good, that is, field has not plenty of moisture, then the field is 
ploughed continuously for about 20 days to get the fine tilth (fine soil got from continuous tillage). The farmers are continuously engaged in their fields to get the better results. From the field observations, the farmers believe that at the end of month of June, it is necessary to again plough the land, so that any unwanted plants (weeds) are removed from the fields. Continuously, after 15 to 20 days the field is repeatedly ploughed again upto the time of sowing of corms, i.e., nearly mid of the August, as experienced farmers believe that the good time for sowing of corms is after first week of August upto first week of September.

Late sowing as well as early sowing of seeds is not recommended in the saffron cultivation. The seeds are generally being sown at the depth of about $8 \mathrm{~cm}$ to $11 \mathrm{~cm}$ (4 to 6 inches), however, there is not any strict rule for the planting of seed corms. A distance of about $7 \mathrm{~cm}$ to $16 \mathrm{~cm}$ is in between of corms is said to be good for the better yield of crop as when the plant grows it produces a number of baby plants as its outgrowth, so farmer has to leave ample space for these outgrowths of the parent plant. The sowing is done by two methods, either by ploughing method or by zoon method. Plough method is practiced by the large number of farmers as it is easy and less expensive method because labour force needed in sowing gets expensive. The corms are sown in rows, and the field is laid out in square beds by providing the drainage channels outside the beds to drain out the excess amount of water after natural showers (rains) or artificial sprinkler irrigation, so that corms may not get damaged. The bed of Saffron seeds is called as "Poshaware" in Kashmiri. Then after the successful sowing of corms, the field needs time to time water showers, till the time of flowering, as the flowering will do start in the very first year, if properly managed and practiced.

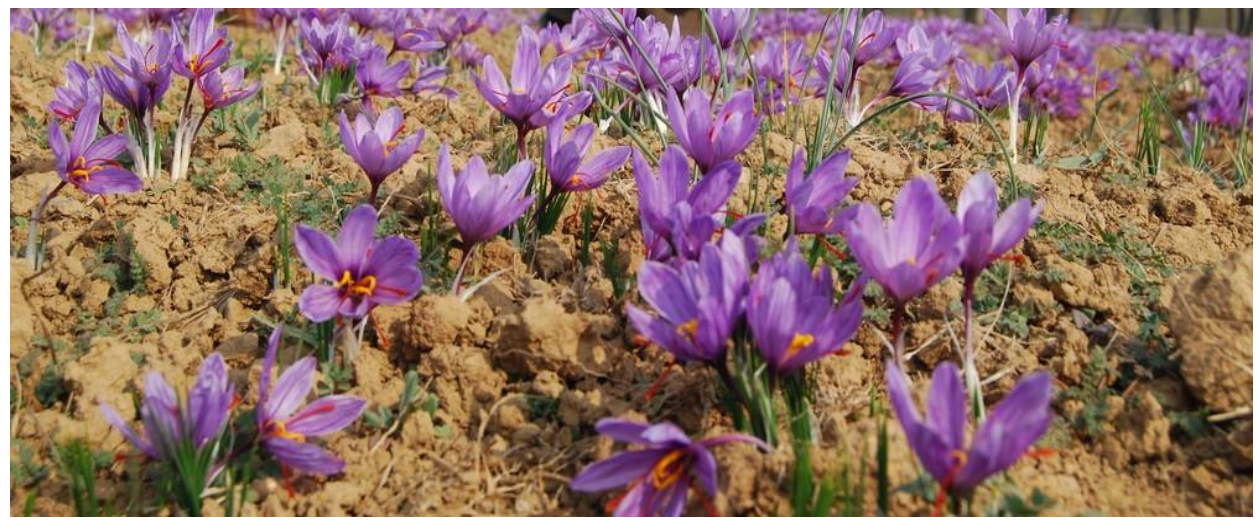

Figure3. Harvesting/Flower plucking time of Saffron in Pampore, Pulwama

After the plucking of flowers in very first year of cultivation, the saffron fields are being left untouched upto the advent of new spring (March/April). The fields are again being prepared for yielding of crop. This time only hoeing is done, i.e., operation of providing aeration to the soil, which is considered very useful for the development of corms. Followed by second hoeing in the mid of August, considered to be very much important for good yield of saffron. The last hoeing is done in September, about 30 to 35 days before the flowering of crop and the repairing of saffron beds and drainage channels is also finalized. These operations of hoeing are very much useful for the growth and health of corms and for the good yield of saffron as it provides the aeration to the soil and corms and through which the delicate stems of flowers emerge on the surface.

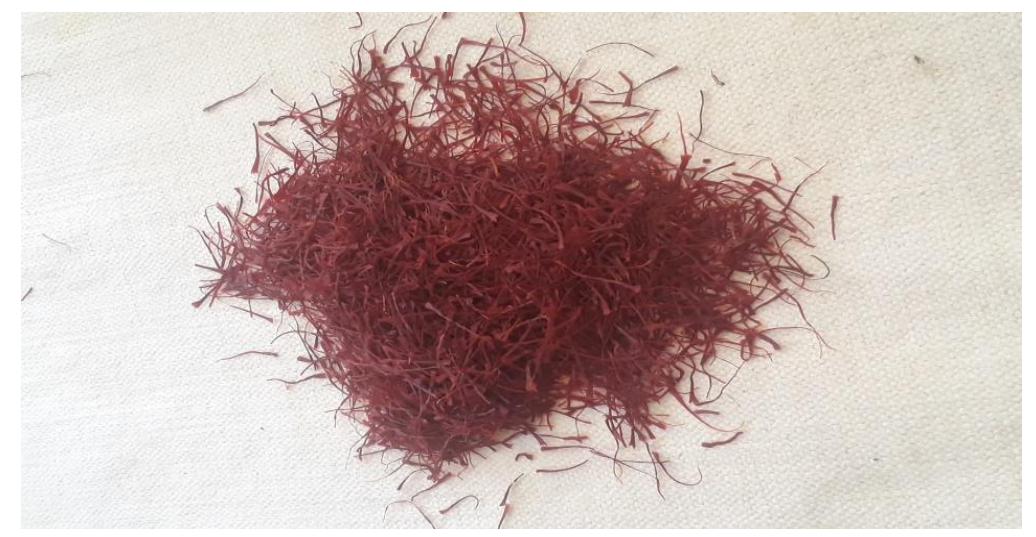

Figure4. Kashmiri Saffron Ready for Use 
It may be noted that the corms may last upto about 7 to 8 years after being sown. However, the lifespan of corms depends mostly upon the type of soil and presence of moisture content in the soil. Adequate moisture content may result in the long lasting of corms, as it has been experienced that the corms may have a lifespan of about 13 to 15 years in certain places. Here, it gives us the intension that for the cultivation of saffron crop particular soil and favourable moisture content in soil is needed.

The flower picking or harvesting season of saffron crop is a very short season, as it starts nearly in first week of November and upto 20th November. At the time of plucking of flowers an optimum number of labour force is required. Farmers also engage their family members in this work and also it needs the skillful labour to pluck the flower from the stem of plant which is done by the fingernails. Farmers also engage their children in this work by providing them knowledge about plucking as they have soft hands. A person who is engaged in the plucking of flowers has to take care of the flowers and move through drainage channels and by stretching their hands and by bending for collecting the flowers so that the blooming flowers do not get blemished. The plucking time starts after the dew drops have disappeared. A good flower collector can collect as much as 3000 flowers a day and these flowers are collected in special kind of baskets made of willow. The plucking is done on alternate days or after every 2 days, depending upon the production and yield.

\section{Production ANd Distribution of SAFFron}

As we know that the Kashmiri saffron is famous for its quality. The production of saffron had been witnessed from very ancient times. The cultivation of saffron is confined to a certain place in the Valley. Pampore area of Pulwama district is considered as the center for its production, and its cultivation is distributed to the adjoining areas of Pampore. Due to the favourable relief features and climatic conditions there, the cultivation of saffron crop stayed in this area. Another feature which favoured its cultivation is special type of soil (wudar) which is found in these Karewas. Its cultivation was diffused to other areas outside Pampore in 1960's. During 1990s, the Saffron cultivation was one of the main cultivation in district Pulwama mainly in the Karewas of Pampore. The area under saffron crop in 1997 was 5707 hectares and the production at that time was approximately 16 million tonnes. During passage of time the area as well as production of this crop showed a declining trend. In 2015, the area under saffron crop was 3674 hectares and production were 9.6 million tonnes with the yield rate of $2.61 \mathrm{~kg} / \mathrm{ha}$. (Jammu and Kashmir, Department of Agriculture, 2015; Table 1).

Table1. Yearly Trends of Area, Production and Productivity of Saffron in Jammu and Kashmir

\begin{tabular}{|l|l|l|l|}
\hline \multicolumn{1}{|c|}{ Year } & \multicolumn{1}{|c|}{$\begin{array}{c}\text { Area } \\
\text { (Ha.) }\end{array}$} & \multicolumn{1}{c|}{$\begin{array}{c}\text { Production } \\
\text { (MTs) }\end{array}$} & $\begin{array}{c}\text { Yield Rate } \\
\text { (KG/ha.) }\end{array}$ \\
\hline 1997 & 5707 & 15.85 & 2.8 \\
\hline 1998 & 4161 & 12.88 & 3.13 \\
\hline 2000 & 2880 & 7.65 & 2.27 \\
\hline 2001 & 2742 & 3.59 & 1.88 \\
\hline 2002 & 3075 & 0.3 & 1.57 \\
\hline 2003 & 2989 & 6.5 & 2.96 \\
\hline 2004 & 2928 & 5.15 & 1.66 \\
\hline 2005 & 2436 & 6.86 & 3.75 \\
\hline 2006 & 3110 & 7.04 & 1.63 \\
\hline 2007 & 3130 & 6.5 & 2.25 \\
\hline 2008 & 3010 & 8.2 & 2.15 \\
\hline 2008 & 3000 & 7.7 & 2.5 \\
\hline 2009 & 3280 & 9.46 & 2.34 \\
\hline 2010 & 3785 & 9.55 & 2.5 \\
\hline 2011 & 3790 & 8.85 & 3.52 \\
\hline 2012 & 3674 & 10 & 2.72 \\
\hline 2013 & 3674 & 11.5 & 3.13 \\
\hline 2014 & 3674 & 15 & 4.08 \\
\hline 2015 & 3674 & 9.6 & 2.61 \\
\hline
\end{tabular}

Source: Jammu and Kashmir Agriculture Department. 
The map shows that the Saffron in Jammu and Kashmir is diffused to some parts of State and when it had been started cultivating in these areas. Pampore area of District Pulwama has highest area under saffron and was the center of saffron cultivation before 1500 A.D, followed by the areas of adjoining to Pampore after 1960's and at present it is being cultivated mainly in districts of Srinagar, Shopian, Anantnag, Budgam and Ganderbal.

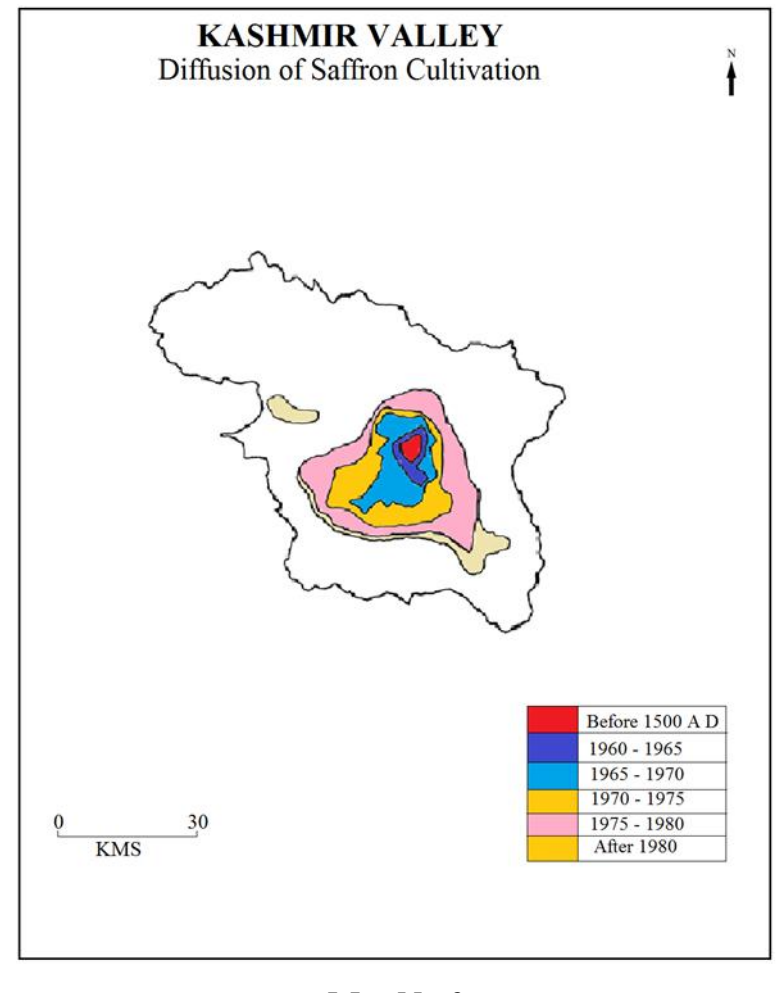

MapNo.2

\section{WANing OF SAFfron Production In JAMmU AND KAShmir}

The area under saffron crop in 1997 was 5707 hectares, production was 15.85 million tonnes and yield per hectare was about 2.8 kilograms and in 2015 the area under this crop was just 3674 hectares, while production had gone down to just 9.6 million tonnes and yield per hectare was as low as 2.61 kilograms, according to the data sources of Department of Agriculture, state of Jammu and Kashmir (Table 3.1 given above). From the last couple of decades, we have witnessed a declining trend of saffron production in the valley of Jammu and Kashmir as the data also reveals. The land under this famous cash crop of state has also shown a waning trend from the past years and the farmers are also now moving out of this cultivation. There are a number of reasons due to which production has shown a waning trend and the people who were engaged in the cultivation of this 'Golden Spice' are now not showing much of the interest in it. Some of the reasons behind this waning trend of saffron in State of Jammu and Kashmir are discussed below:-

\subsection{Non-Availability of Good Quality Corms}

Botanically the plant having triploid, fails to set seeds, and thus is propagated vegetatively through corms. Good quality and disease free corms result in the good production of crop. A corm producing flower contains 10-12 buds and each sprouting bud produces a cormel. Pandey et, al. (1979) found larger corms produced more flowers and leaves. In Kashmir the corm seeds which are sown mostly in the fields are of about $2 \mathrm{~cm}$ in diameter and $10 \mathrm{~g}$ in weight. Here the farmers have non-availability of sound quality corms that is why they go for the low standard corms. Due to which the yield from these corms is low. It is also seen that if the good quality corms are available then they have high rates which a small farmer is not able to buy them. Government also provided the facilities to farmers to buy the corms at subsided rates, but the majority was much away from getting these benefits. Small corms do not have the potential to produce flowers in the first year (Sadeghi, 1983), while corms larger than $2.5 \mathrm{~cm}$ in diameter only flower in the very first year (DeMastro and Ruta, 1993). Therefore, quality of the corms matters a lot in the production of Saffron crop. These corms have very high rates and government should try to make available good quality corms for these farmers at reasonable rates. 


\subsection{Lack of Adequate Irrigation Facilities}

From the very beginning, the saffron fields were completely dependent on the rain and if there were no rain there was no production, that rains have direct relationship with the production of Saffron. Saffron crop needs the time to time showers and mostly the crop has need of water during its initial stages. Srivastava (1963), reported that areas receiving 100-150 cm of well distributed rainfall with snow in the winters are best suited for Saffron cultivation, and rains in September are essential for meeting the water requirements of corms for good flower yields. The State of Jammu and Kashmir faced an acute drought in 1999-2003 (Alam, 2007), and during this period productivity was reduced from $3.12 \mathrm{~kg} / \mathrm{ha}$ to $1.57 \mathrm{~kg} / \mathrm{ha}$. However, in $2004-05$, favourable rainfall improved the productivity also to $2.96 \mathrm{~kg} / \mathrm{ha}$.

So, for getting better productivity there is a need of providing artificial irrigation to the fields, but, at ground levels it also seems that there is no facility to the farmer to provide their fields an adequate irrigation. Government under the National Saffron Mission, set up in 2010, to rejuvenate saffron cultivation in Jammu and Kashmir, assured the farmers to provide the irrigation facility to their fields but a little of their intension was seen. Therefore, cultivators were left with no choice to switch to high-density crops such as apple, walnut and garlic, etc. While most farmers denounced of idleness, some were reportedly obstructive in the laying of pipelines, fearing land damage. Distressed by the delay for the sprinklers to become operative, some of the enterprising individuals even set up their own irrigation facilities.

\subsection{Lack of Technology}

The world is fastly getting industrialized and use of technology is seen in every sector. Here the saffron is being grown by indigenous technique. To improve the yield and productivity this sector also needs the latest technology for improvement. We can see the countries, where saffron is being cultivated use the technological tools in sowing, harvesting and in post harvesting process. Here, the farmers are lacking the new technologies and machinery to get benefitted from them. The outdated technology is also considered as the cause of fertility loss of soil and in decrease in production. There is also the need of educating and to bring awareness amongst the farmers about the post harvesting methods and use of techniques for storing of the crop. There is a great amount of crocin (14-17\%) in the fresh stigmas of Kashmiri saffron (Nehvi et, al. 2007). The Crocin content present in stigmas of Kashmiri saffron is found to have decreased (9-11.5\%) after harvesting and storing process because of unawareness about the postharvest handling, right time and right stage of separating the stigma from style, popularizing the use of solar dryers, branding, etc. Kashmir is lacking in terms of production, with an average yield of 2.23 $\mathrm{kg} / \mathrm{ha}$ as compared to $8.24 \mathrm{~kg} / \mathrm{ha}$ in Spain and $10.0 \mathrm{~kg} / \mathrm{ha}$ in Italy (Shahnaz et, al. 2013). So, it is obvious to add it here that with the help of modern technological tools, the production can be increased and the farmer will get benefit from it and will make cultivation economically viable and ecologically sustainable.

\subsection{Absence of Good Fertilizers and Disease Control Pests}

The intensive cultivation and monoculture of Saffron in saffron-growing areas of Kashmir valley, together with the continual use of diseased material has resulted in the frequent occurrence of corm rot diseases caused by pathogens such as, Fusarium moniliforme var. intermedium, a non-sporulating basidiomycetous fungus (Dhar, 1992), Macrophominia phaseolina (Thakur et, al.1992), Fusarium oxysporum, F. solani, and Fusarium moniliforme (Wani, 2004). Out of these diseases, corm rot of Saffron caused by F. oxysporum and F. solani is examined to be most destructive in Kashmir (Wani, 2004). These diseases directly affect the corms of saffron. If the corm seeds are injured there are maximum chances of that the corms will get damaged. With the result the farmer has to go for new seed corms or has to use the particular and good quality fertilizers and pesticides for controlling these diseases. In Kashmir it is seen that almost every year these diseases effect the cultivation and ample proportion of produce gets reduced. Dhar (1992), observed that although none of the Saffron-growing areas of Kashmir valley were free from disease (almost 100\% disease incidence). Nehvi (2003), however, reported the incidence of corm rot as $46 \%$ in traditional saffron-growing areas of Pampore. These studies reveal that there is a need of providing the quality fertilizers and pesticides for the control of these diseases. The application of different doses of Carbendazim against corm rot of Saffron can result in better flowering yields (Shahnaz et, al. 2013). Under the Saffron Mission 2010, Government provided the facility centers at many places in the saffron growing areas, but from the empirical observation, it revealed that at ground level it was seen as a failed mission or benefitted at a negligible rate. 


\subsection{Lack of Optimum Profit for Cultivators}

As discussed above, the farmers suffer from these problems yet he continues with the cultivation of Saffron but he does not earn optimum profit to enjoy the good life. After a conversation with the cultivator, namely Farooq Ahmad Wani (2018, August 20), Saffron Cultivator, 1:00pm Pampore in district Pulwama, Jammu and Kashmir, India, told that, "at certain times we don't get a suitable rates for our products as we are lacking the facility of an authorized market where we can sell our products and get the optimum profits even sometimes we have to sell our final good quality products on very low rates because of the Dalals (middlemen), as they have to earn their own share or commission from our product", as the marketing of saffron is mainly in the hands of these Dalas and marketing firms. The price of the saffron in State is generally determined by these firms and Dalas. Due to this reason they are moving towards a period where they have to stop cultivating this golden spice and switch to any other farming or any other work. Government has also not taken any concrete steps towards providing some incentives or creating any market where they can sell their product on suitable rates. Under Saffron Mission 2010, the government of state started a programme but was not strictly implemented, and only those persons got benefitted who had any connections to the higher authorities or who had any links with the marketing firms in state or outside state which take their product to the national and international markets. The small farmers just sell their production to these big firms and middlemen to clear their debts, and under these conditions farmer sell their produce at very cheap rates and gets negligible profit. There are very few farmers who sell their produce directly to the dealers in national markets, like Delhi, Mumbai, Kolkata, Amritsar, etc.

\subsection{Impact of Climate Change}

Apart from the above problems, there is major reason of climate change in the Valley which has affected its production and yield. The livelihood of the society can be badly affected directly or indirectly due to the climatic changes. Climate distortion has surfaced as an important issue ever to encounter mankind. The prolonged dry spell in the months in which saffron has a need of showers left the farmers worried. In Kashmir, the saffron crop is mainly dependent on rains and if rains are received at the sprouting and pre-flowering stages, flowering is optimum and saffron yield is good. Due to insufficient rainfall, the state has seen the lowest productivity in the past 2 to 3 decades. It was seen in the State of Jammu and Kashmir which faced an acute drought in 1999-2003 (Alam, 2007), and during this period productivity was reduced from $3.12 \mathrm{~kg} / \mathrm{ha}$ to $1.57 \mathrm{~kg} / \mathrm{ha}$. However, in 2004-05, favourable rainfall improved the productivity also to $2.96 \mathrm{~kg} / \mathrm{ha}$. It means that without rainfall the productivity of Saffron experiences a severe downfall. The variations in the time of precipitations in valley has been connected with waning trend of Saffron as experienced by the farmers that if there is less snowfall in the winter season it effects directly the productivity and yield in the succeeding year. As in winter season snow covers the saffron fields and provides moisture to the corms continuously upto the next spring season and corms do not get effected and remain healthy. It is necessary that corms have optimum moisture level during the winter (dormant) season otherwise corms get infected and don't produce the outgrowth. In the spring season when first hoeing is done the soil gets aerated and after the first hoeing the fields need time to time rain showers upto the time of flowering. For precipitation, mountainous parts of valley have shown a drastic decrease in precipitation (10.3 $\mathrm{mm} /$ year) while as flood plains have shown relatively less rate of decrease of $3.6 \mathrm{~mm} /$ year and with foothills and Karewa's having moderate rate of decrease 6.3 and $5.8 \mathrm{~mm} /$ year, respectively (Shafiq et, al. 2018).

\section{NATIONAL SAFFron MiSSION (NSM) 2010}

In August 2010, the Union Government of India has approved a plan of approximately Rs. 373 crore under National Saffron Mission Programme (NSMP) to rejuvenate the saffron production in Jammu \& Kashmir. It was planned that Rs.373 crore will be spent under the National Saffron Mission Programme till 2014 while Rs.9.50 crore has been distributed among the farmers for replantation of corms (www.gktoday.in).The Mission commenced from 2010 and would have been completed in 4 years (2014) but in 2015 it was then extended for 2 more years and an additional amount of 40 crores were allotted for rejuvenating 800 hectares of saffron fields for getting the better results and to make the project successful (Saleem, 2015). As discussed earlier, over the past years as saffron production slumped in Jammu and Kashmir, government mulled an action plan to come to the rescue of the growers. That's how the highly ambitious NSMP was sanctioned by the Government of India in 2010 
to prevent the declining production of saffron in the Valley (Rashid, 2018). Under the scheme, every farmer was promised a sum of Rs. 25,000 for each Kanal (unit) and would be encouraged to adopt new technologies like seed diversification and transformation (Pal, 2018). The project was at improving the saffron production and yield by providing quality seed and sophisticated water supply. The task was entrusted in the hands of the Agriculture Department and the Mechanical Engineering Department of State for completing the objectives under the scheme.

Table2. Year Wise Financial Requirement (Rupees In Lakhs)

\begin{tabular}{|c|c|c|c|c|c|c|}
\hline Components & Inputs & 2010-11 & 2011-12 & 2012-13 & 2013-14 & Total \\
\hline Replanting/Rejuvenation & $\begin{array}{l}\text { Digging \&relying } \\
\text { cost }\end{array}$ & -- & 7695.0 & 5821.87 & 5290.31 & 18807.18 \\
\hline IINM/IDM/IPM & -- & -- & 570.0 & 431.25 & 391.87 & 1393.12 \\
\hline $\begin{array}{l}\text { Quality corm Production } \\
\text { under Public sector }\end{array}$ & Corm/other inputs & 203.0 & 203.0 & 188.50 & -- & 594.50 \\
\hline $\begin{array}{ll}\text { Strengthening } & \text { of } \\
\text { Irrigation System } & \end{array}$ & $\begin{array}{l}\text { Tube } \\
\text { well/Sprinklers }\end{array}$ & 1454.0 & 1101.5 & 974.25 & -- & 3529.75 \\
\hline $\begin{array}{l}\text { Enhancing } \\
\text { Quality }\end{array}$ & Dryers & 105.0 & 165.0 & 165.0 & 165.0 & 600.00 \\
\hline Saffron Mechanization & $\begin{array}{l}\text { Planters/Weeders } \\
\text { etc. }\end{array}$ & 167.50 & 82.50 & 62.50 & 62.50 & 355.00 \\
\hline $\begin{array}{l}\text { Infrastructure } \\
\text { Vermicompost units }\end{array}$ & & 34.20 & 57 & 57 & 79.2 & 227.4 \\
\hline Biofertilizer Units & & 20.0 & -- & -- & -- & 20.00 \\
\hline $\begin{array}{l}\text { Corm handling } \quad \& \\
\text { storage Units }\end{array}$ & & 30.0 & -- & -- & -- & 30.00 \\
\hline $\begin{array}{l}\text { Transfer } \\
\text { Technologies }\end{array}$ & & 49.87 & 50.12 & 23.10 & 20.10 & 143.49 \\
\hline $\begin{array}{ll}\text { Establishment } & \text { of } \\
\text { weather Station } & \end{array}$ & & 100 & 100 & -- & -- & 200 \\
\hline $\begin{array}{lll}\text { Quality } & \text { Testing } \quad \& \\
\text { Marketing } & & \\
\end{array}$ & & 1651.0 & 185.0 & 185.0 & 185.0 & 2206.00 \\
\hline Research \& Development & & 91.24 & 241.60 & 47.99 & 35.89 & 416.72 \\
\hline $\begin{array}{l}\text { Project Monitoring } @ \\
1 \% \text { of Project Cost }\end{array}$ & & 38.06 & 103.30 & 79.56 & 62.30 & 283.22 \\
\hline Grand Total & & 3943.87 & 10434.02 & 8036.02 & 6292.17 & 28806.08 \\
\hline
\end{tabular}

Source: Project for Economic Revival of J \& K Saffron Sector

\subsection{Objectives of the Mission}

- Rejuvenation/replanting of existing Saffron area for improving productivity.

- Improving Soil Health by INM (Integrated Nutrient Management), IPM (Integrated Pest Management), and IDM practices.

- Standardization of quality corm production in public nurseries.

- Strengthening the Irrigation System.

- Enhancing product quality through improved post-harvest handling.

- Mechanization.

- Establishment of Weather Stations.

- Infrastructure Development.

- Transfer of Technologies.

- Quality testing and marketing.

- Enhancement of Research and Extension capabilities.

- Delineation of packaging practices for Saffron.

- Dissemination of weather forecast, market alerts, etc. through SMS.

- Market intervention through e-trading and establishment of Electronic Auction Centre.

- Grading, packing and branding. 


\subsection{Outcomes of National Saffron Mission (NSM)}

\subsubsection{Anticipated Results}

- Productivity Enhancement : It was said to be the productivity of Saffron crop will increase from $2.50 \mathrm{~kg} / \mathrm{ha}$ to $5 \mathrm{~kg} / \mathrm{ha}$ and total production will get enhanced from $9.46 \mathrm{MT}$ to $18.5 \mathrm{MT}$ and that too without adding up new area.

- Public Sector Nurseries: Under Objectives/Aims of the Mission, it was said that further 800 hectares of area will be brought under Saffron Crop and for that Public Sector Nurseries will be established.

- Saffron Recovery: Sophisticated post-harvest techniques will be practiced like Quality Saffron Drying to improve saffron recovery by $27 \%$, which in turn will increase the production by 5 million tonnes.

- Price Discovery through Transparent Transactions: This will produce well organized market system which in turn will reduce intermediate costs (brokerage/dalas), enhance farmers' price realization which will help in availing better quality Saffron for customers (Economic Revival of J\&K Saffron Sector 2010).

\subsubsection{On Ground Results}

From the above study, it seems that the Mission has fully supported the cultivators and had satisfied the authorities and the objectives which were being fulfilled under this Mission had been completed. But, the ground situations are quite different from the expected results. From the various studies done, it seems to be the Mission has almost failed and had not produced the satisfactory results. The ambitious National Saffron Mission, initiated in 2010, was born out of a vision to revive the traditional saffron cultivation in areas of Jammu and Kashmir.

A drip irrigation system and Rs. 24 crore for investment in a saffron park were also proposed. Unfortunately, the grandeur of the plan was not channeled by the government into substantial action on the ground. Irrigation which is the key component of the scheme is now turning into the biggest reason behind its failure. Under the mission, 126 bore wells had to be dug to provide irrigation facilities to nearly 2,400 hectares of saffron land. However, on the ground, only 101 borewells were dug under the central scheme, of the total 126 proposed (Pal, 2018). In a study conducted by the Shere-Kashmir University of Agricultural Sciences and Technology in 2010, it was found that 128 borewells were needed to cultivate saffron. However, the Public Health Engineering and the Irrigation and Flood control departments have only constructed 3 bore wells since 2010 (Saleem, 2015). Another study revealed that, in first five years of project, the government has failed to set-up the proposed number of bore wells, Officials in Agriculture Department says that the mission envisaged with 100 percent project support. "But, the fact is only four of the said bore wells are fully functional" (Amin, 2016). The reality revealed the different situation on ground, after interacting with the local cultivators there. One of the cultivators, namely, Mohammad Sultan Wani said, under the scheme only few people were benefitted but not the all, those who have some approach to higher authorities/officers were benefitted and the farmer who works hard witnessed nothing beneficial from the project had even the proposed project has in turn destroyed our crop and government has only made fake plans and promises. On talking to some Officials, they termed the mission as a huge success, but on ground situation tells everything about the fact.

Another reason for the failure of the Mission is seen the lack of knowledge about the technology and latest techniques practiced by the farmers. The farmers used the techniques and equipments provided by the authorities, but, were not given the satisfactory knowledge about those things. No doubt camp was being organized by the authorities for providing the knowledge about the use of equipments, techniques, fertilizers and other facilities but, not for everyone. There was seen a very huge/drastic change in the saffron cultivation but not that satisfactory, but still a lot needs to be done (Raja et, al. 2018).

Thus, from the above discussion, it can be concluded that the Nation Saffron Mission started in 2010, has done much for the welfare of the Golden Crop, but something is still missing there, and lot more needs to be done under the mission for benefitting each farmer and tackling the problems of cultivators and getting better results. But, upto this point it can be said that the Mission has almost failed to satisfy the people due to the lack of proper management and supervision. 


\section{SUGGESTIONS}

From the above study, the problems which are being faced by farmers are due to the lack of basic facilities and sophisticated techniques by which cultivation of crop can be improved. The world is fastly growing with the latest technology and in this developed and modernized world, if anyone has to excel in his/her field, they have opt for latest technology. The countries like Iran and Spain, where saffron is being cultivated use the modern tools and techniques in their farms and that is why there is a huge difference in production and productivity of saffron between them and us.

And if we also want to make our production levels high we need to keenly look into the matter on ground levels and try to fix out the loopholes which are acting as barriers in the development of this crop. The current scenario suggests that if concrete steps are not taken in this matter, the crop might get extinct from the soils of Jammu \& Kashmir, because the farmers are fastly making their path towards other sources for their livelihood and the area under saffron is diminishing continuously. Here, the need of an hour is to first protect the saffron cultivated area from declining by providing some good incentives to the cultivators of Saffron in the State of J \& K. Secondly, by taking serious actions, making concrete efforts and providing sophisticated facilities and latest technology on ground levels to farmers, so that, they will continue to cultivate this crop and take the production to higher levels. It will only happen if the concerned authorities will keenly intervene in this matter and try to make actions and statements on ground levels.

\section{CONCLUSION}

In Kashmir, the cultivation of saffron has been started from the very ancient times nearly from about 750 A.D. The study revealed that Kashmiri Saffron had lost its quality and had shown a waning trend in the productivity and yield from last 20 to 25 years. Saffron is being cultivated mainly in the Karewas of Pampore and its adjoining areas. Soil in the Karewas has also lost some of its fertility due to the old techniques used by farmers in their fields. Other factors responsible for decline in production are non-availability of some basic facilities to farmers. Variation in precipitation level has also added a fuel in the waning trend of Saffron produce. A goodwill step taken by Union Government of India along with the Government of Jammu \& Kashmir in the form of National Saffron Mission in 2010 also shows that there is something missing from the side of concerned authorities which hinders the Mission from getting fruitful results. Finally, we can say that by providing the basic facilities to the cultivators which have been discussed here and by taking concrete steps for the success of Saffron Mission can result in the increase of production and also will boost the cultivators to put some more area under this Golden Crop.

\section{REFERENCES}

[1] Alam, A. (2007), Status and prospects of mechanization in Saffron cultivation in Kashmir. ActaHorticulturae. 739, 383-388.

[2] Amin, Z. (2016). indianexpress.com/article/india/india-news-india/five-years-and-rs-250-crores-laternational-saffron-mission-on-path-of-failure-in-jk/.

[3] Behnai, M.R., Estilai, A., \&Ehdaie, B. (1999). Application of Fertilizers for increasing saffron yield, Journal of Agronomical Sciences. 182, 9-5 pp.

[4] DeMastro, G., Ruta, C. (1993).Relation between corm size and saffron (Crocus sativus L.) flowering. ActaHorticulturae. 344, 512-531.

[5] Dhar, A. K. (1992). Bio-ecology and control of corm rot of Saffron (Crocus sativus L.). MSc. Thesis, Sher-e- Kashmir University of Agricultural Sciences and Technology of Kashmir, India. 109pp.

[6] Economic Revival of J\&K Saffron Sector Project (2010). Department of Agriculture \& Cooperation, Ministry of Agriculture, Govt. of India and Government of J\&K.

[7] Farooq, M., \&Meraj, G. (2016). Saffron in J \&K, (J \& K ENVIS NEWSLETTER) - State of Environment \& its Related Issues in J \& K, Volume 3 - Issue 3, July - September

[8] Husaini, A., Bhat, M.A., Kamili, A., \& Mir, M.A. (2013). Kashmiri Saffron in Crisis. Article in Current Sciences.

[9] Husain, M. (2000). Systematic Geography of Jammu \& Kashmir, Rawat Publication, New Delhi - 110002, $147-155 \mathrm{pp}$.

[10] Nehvi, F.A. (2003). Problems and Prospects of Saffron Improvement in India. In proceedings of International Seminar on Industrial use of Biotechnology, $27^{\text {th }}$ September $-1^{\text {st }}$ October, 2003, Iran, 14 pp. 
[11] Nehvi, F.A, Wani, S.A, Dar, S.A, Makhdoomi, M.I., Allie, B. A., \& Mir, Z. A (2007). Biological Interventions for enhancing Saffron productivity in Kashmir. ActaHorticulturae. 739, 375- 382.

[12] Pal, S. (2018). newsclick.in/farmers-bear-brunt-failure-national-saffron-mission.

[13] Pandey, D., Pandey, V.S., \&Srivastava, R. P. (1979). A note on the effect of the Size of Corms on the Sprouting and Flowering of Saffron. Progressive Horticulture. 6, 89- 92.

[14] Raja, N. Muzaffar, S., Wani, N, I., \& Rashid, U. (2018). National saffron mission in Kashmir: An impact analysis. Journal of Pharmacognosy and Phytochemistry, 7(4) 3457-3464.

[15] Rashid, A, (2018). freepresskashmir.com/2018/09/22/ from-35kgs-earlier-to-1kg-yield-now-successfulsaffron-mission-paves-way-for-apples-in-pampore/.

[16] Sadeghi, B. (1983). Effects of Corm weight on flower initiation of Saffron. Scientific and Industrial Research Organisation of Iran, Khorasan Institute, Iran. 39 pp.

[17] Saleem, V. (2015). downtoearth.org.in/new/agriculture/ national-saffron-has-failed-due-to-governmentinsensitivity-say-growers-50476.

[18] Shafiq, M. U., Rasool, R., Ahmed, P., \&Dimri, A. P.(2018).Temperature and Precipitation trends in Kashmir Valley, North Western Himalayas. Theoretical and Applied Climatology (Springer), 11 pp.

[19] Shahnaz, E., Misger, F. A., \& Kumar, A. (2012), On Farm Treatment on Corm Rot of Saffron (Crocus sativus L.) in Pulwama District of Kashmir Valley. Research Journal of Agricultural Sciences,4,1.

[20] Srivastava, R.P. (1963), Cultivation of Saffron in India. Fertilizers News, 8, 9 - 16.

[21] Thakur, R. N., Singh, C., \&Kaul, B. L. (1992). First Report of Corm rot in Crocus sativus L. Indian Phytopathology. 45, $278-282$.

[22] Wani, A. (2004), Studies on Corm rot of Saffron (Crocus sativus L.), Phd. Thesis, Sher-e-Kashmir University of Agricultural Sciences \& Technology of Kashmir, India. 108 pp.

[23] www.gktoday.in/current-affairs/rs-373-crore-to-be-spent-till-2014-under-national-saffron-mission/.

\section{AUTHORS' BIOGRAPHY}

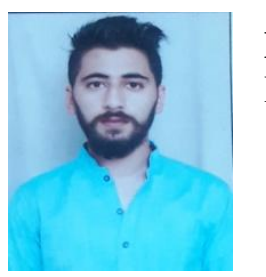

Daawar Bashir Ganaie, Post-Graduate Student in Department of Geography, Punjabi University Patiala, India.

Citation: Daawar Bashir Ganaie, Yadvinder Singh. "Saffron in Jammu \& Kashmir”. International Journal of Research in Geography. vol 5, no. 2, 2019, pp. 1-12. doi: http://dx.doi.org/10.20431/2454-8685.0502001.

Copyright: (C) 2019 Authors. This is an open-access article distributed under the terms of the Creative Commons Attribution License, which permits unrestricted use, distribution, and reproduction in any medium, provided the original author and source are credited. 